\title{
Las conexiones escenográfico-psicológicas entre Cuando los ángeles caen y La trilogía de apartamentos de Roman Polanski
}

The scenographic- psychological connections between

When the angels fall and The apartment's trilogy

by Roman Polanski

Alberto Román Padilla Díaz

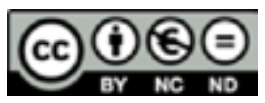

Esta obra está bajo una licencia Creative Commons

Reconocimiento-No comercial-Sin Obra Derivada 


\title{
Las conexiones escenográfico-psicológicas entre Cuando los ángeles caen y La trilogía de apartamentos de Roman Polanski
}

\author{
The Scenographic-psychological Connections between \\ When the Angels Fall and The Apartment's Trilogy \\ by Roman Polanski
}

\author{
Alberto Román Padilla Díaz ${ }^{1}$ \\ Universidad de Córdoba \\ España
}

Recibido: 26 de marzo 2018 Aprobado: 22 de agosto 2018

\section{Resumen}

La gama de géneros con las que ha trabajado el cine de Roman Polanski es tan amplia que cuesta hallar algún estilema que encadene visual y teóricamente su filmografía. Sin embargo, puede que el tratamiento de la escenografía sea dicho elemento unificador. Este escrito indaga sobre esta hipótesis y propone un nombre para este mecanismo cinematográfico: dispositivo escenográfico-psicológico. El objeto de estudio elegido para ello es el cortometraje Cuando los ángeles caen, que fue realizado antes del debut cinematográfico del director. En él, se propone esta lectura y se establecen conexiones estilísticas con tres películas fundamentales, a nivel escenográfico, de su futura filmografía, conocidas como Trilogía de apartamentos.

Palabras clave: Roman Polanski, dispositivo escenográfico-psicológico, no-lugares, prisión, expresionismo

' Doctorando en la Universidad de Córdoba, España. Correo electrónico: alberpd@hotmail.com 


\begin{abstract}
The variety of genres of Roman Polanski's films is so extensive, it is hard to find a common theme that connects visually and theoretically his filmography. However, the treatment of the scenography may be that common element. This paper investigates this theory and gives name to this cinematographic mechanism: "scene-psychological device". The chosen research is the short film When the Angels fall which was accomplished before the director's cinematographic debut. It's not only tenders his reading, but it establishes a stylistic link between three fundamental films, in a scenography way, of his future filmography, called Apartment's trilogy.
\end{abstract}

Keywords: Roman Polanski, scene-psychological device, non-places, prison, expressionism. 
Las conexiones escenográfico-psicológicas entre

Cuando los ángeles caen y La trilogía de apartamentos de Roman Polanski

Artículos

\section{Introducción}

En su libro sobre el género del terror en la cultura Pop, Danza macabra, Stephen King citaba que, para conseguir una poderosa historia de terror, lo que él llama una verdadera danza macabra, esta tenía que estar conformada por "aquellos momentos extraordinarios en los que el autor es capaz de aunar la mente consciente con la inconsciente mediante una idea poderosa" (King, 1981, p. 29). Si adaptáramos esta afirmación al cine de Roman Polanski, esa idea poderosa vendría a ser el tratamiento concreto que se otorga a las escenografías y atmósferas de sus películas, donde "el decorado no siendo más que un espectáculo pasivo en el mismo, se da a trozos y sintetizado al espectador. El arte de explotar cinematográficamente ese decorado es pues tan importante como su concepción" (Avron, 1990, p. 57). Sobre este punto versará este ensayo.

El tipo de escenografía aquí analizada no abarca, únicamente, a la miscelánea de decorados $u$ otros elementos espaciales que compongan una obra dirigida por Roman Polanski -o, por lo menos, no se reducirá únicamente a la mera citación de estos- sino a las claves, significantes y significados de los mismos. Estos factores contribuyen a esa intensificación del drama de la que Bazin (1990) habla en la siguiente cita:

No puede hacerse teatro más que con el hombre, pero el drama cinematográfico puede existir sin actores. Una puerta que golpea, una hoja al viento, las olas rompiendo en la orilla pueden intensificar el efecto dramático. Algunas piezas maestras del cine utilizan al hombre simplemente como un accesorio, como una comparsa, o en contrapunto con la naturaleza, que constituye el verdadero personaje central (p. 179).

El objeto de estudio de este ensayo vendría a ser el cortometraje Cuando los ángeles caen (1958) y el trabajo conocido como la Trilogía de apartamentos o Trilogía de la reclusión compuesta por las películas Repulsión (Repulsion, Roman Polanski, 1965), La semilla del diablo (Rosemary's baby, Roman Polanski, 1968) y El quimérico inquilino (Le locataire, Roman Polanski, 1976). En esta parcial muestra del cine de Polanski, los enclaves escenográficos dan lugar a una visión espacialmente simbólica y pesimista de lo que viven los personajes, con lo cual, llegan a replantearse la noción psicológica de sí mismos. En otras palabras, la escenografía vive una evolución paralela al declive psicológico de los personajes, lo que da forma a un necesario e interesante ejercicio teórico-práctico de lo que podríamos denominar: dispositivo escenográfico-psicológico, de las películas del director francés. Sobre esta cuestión versa la investigadora Helena Goscillo (2006) en la siguiente reflexión sobre la filmografía de Polanski:

Scholarship on Polanski primarily focuses on his obsession with evil, violence, voyeurism and power relations, more briefly registering his purely visual solutions to cinematic issues, his transformation of claustrophobic settings into psychic space ... and of everyday

ESCENA. Revista de las artes, 2019, Vol. 78, Núm. 2 (enero-junio), pp. 12-36 
objects and landscapes into symbols [La erudición en Polanski se centra, principalmente, en su obsesión con el mal, la violencia, el "voyeurismo" y las relaciones de poder, más brevemente al aportar sus soluciones puramente visuales a cuestiones cinematográficas, su transformación de los enclaves claustrofóbicos en espacios psíquicos ... y los objetos cotidianos y paisajes en símbolos] (p. 23).

El cortometraje a analizar aquí: Cuando los ángeles caen (Gdy Spadaja Anioly, 1958) es un perfecto ejemplo de ello, por dos razones. Por una parte, cumple con el factor de que, en dicha obra, un espacio claustrofóbico (un baño público) acaba mermando en un espacio puramente psicológico, como menciona Goscillo en su cita. Un tratamiento que se correspondería con las operaciones escenográfico-psicológicas que sugerimos para este estudio. Por otra lado, el corto es una factible muestra de este tratamiento más psicológico del escenario. Un tratamiento que, si nos atenemos al año de realización del cortometraje, ya se efectuaba incluso antes de los largometrajes posteriores de Polanski, ya que el primero de ellos, El cuchillo en el agua (Noz W Wodzie) es de 1962 y el cortometraje de Cuando los ángeles caen de 1958, como ya hemos citado.

Es por ello que, a lo largo del análisis se establecerán comparaciones entre las operaciones escenográfico-psicológicas que realiza el cortometraje con otras operaciones visual-espaciales de una serie concreta de filmes del director. En particular, con las películas Repulsión, La semilla del diablo y El quimérico inquilino. La comparación específica con estas tres películas no es casual, estamos hablando de una serie de películas conocidas como Trilogía de apartamentos o Trilogía de la reclusión como menciona muy acertadamente Joaquin Vallet ${ }^{2}$, ya que en las tres película se juega a establecer un paralelismo entre la reclusión psicológica de los personajes protagonistas y unos apartamentos también recluidos. Se trata de una serie de películas de terror psicológico, cuyo actante común espacial son tres apartamentos de tres enclaves cosmopolitas del mundo: Londres, Nueva York y París, respectivamente. En ambos casos, tanto en el corto como en las tres películas, el espacio cinematográfico y lo que les afecta a los personajes es lo que da lugar al avance de las tramas, o bien lo que nos las explica. Son espacios que evolucionan, paralelamente, a la psicología del personaje.

La elección comparativa del corto con este trío fílmico, y no con otras películas de la amplia filmografía del director francés, se debe, fundamentalmente, a la evidencia de cómo el espacio de los tres apartamentos es el desencadenante único de la trama; una característica que solo poseen esas tres películas. Esto es algo que, por poner un ejemplo ilustrativo,

2 "Efectivamente, El quimérico inquilino cierra la trilogía iniciada con Repulsión y continuada con La semilla del diablo, que bien podríamos denominar la Trilogía de la reclusión (Vallet, 2018, p. 195). 
posterior y dirigido por Polanski, no sucede en El Escritor (The Ghost Writer, 2010) donde, el eje escenográfico era importante, pero no determinante de las situaciones que se producían a lo largo del filme. Más bien, lo que daba lugar a los acontecimientos era una trama política concreta del arco argumental de dicho thriller.

En la creación de este estudio, se ha empleado una metodología de análisis fílmico del cortometraje de aquellas secuencias en las que el dispositivo escenográfico-psicológico es más notable. Para luego, comparar dichas operaciones escenográficas del cortometraje con la respectiva operación u operadores escenográficos de alguna de las tres películas sobre apartamentos. Conviene especificar que la forma de comparación es la siguiente: el corto por un lado y las tres películas conjuntas por otro; de modo que, dichas tres películas sean vistas como un único volumen audiovisual a nivel teórico-práctico, pero que está subdivido en tres partes.

En lo que atañe al marco teórico ha sido muy importante la obra Los No-Lugares: espacios del anonimato (1992) del antropólogo Marc Augé, cuyo término No-Lugares ha sido necesario y prácticamente imprescindible a la hora de abordar y analizar los espacios ante los que nos hallamos, como bien se mostrará en el análisis. Esto tampoco indica que, esta investigación se haya desentendido de las aportaciones de los investigadores nacionales e internacionales del cine de Polanski como Dominique Avron, Joaquin Vallent, Montse Hormigos Vaquero, Alexander Tylski, entre otros, incluso de aportaciones del propio director en su autobiografía publicada.

\section{La predilección estético-escenográfica en Cuando los ángeles caen y las películas de apartamentos}

Antes de pasar al análisis repasaremos, teóricamente, la importancia de la escenografía y la ambientación en el cortometraje y las tres películas. Pero, sobre todo, cómo estas modalidades prevalecen y tienen más relevancia que la forma narrativa. El cortometraje Cuando los ángeles caen, como ya dijimos antes, fue estrenado entre 1958 y 1959. Al igual que los anteriores cortometrajes del director, también fue un ejercicio para la escuela de cine de Lodz, como bien relata cualquier fuente sobre el cine de Polanski que se consulte. Se trata de "un trabajo donde lo más novedoso es la compleja estructura guionística en flashbac$k s . .$. todos los saltos se dan mediante fundidos encadenados que pasan del blanco y negro al color y viceversa" (Moldes, 2004, p.121), cuya intención principal, según el director era:

L'idée m'était venue à la lecture d'une nouvelle dans un journal. II s'agissait de la vielle tenancière d'un chalet d'aisance qui avait eu une vision mystique... Telle fut la génese de Quant tombent les anges. Je désirais que le film donne une impression de largeur malgré sa durée de quelque vingt minutes. Par-dessus tout, je le voulais romanesque, presque 
pompier de style- que le public comprenne facilement qu'il s'agit tassait des rêveries d'une vieille femme proche de la fin de sa vie [La idea procedía de un relato corto publicado en un periódico acerca de la anciana encargada de unos urinarios que experimenta una visión mística ... Esta era la génesis de Cuando los ángeles caen. Deseaba que la película tuviera una impresión de amplitud, a pesar de sus veintitantos minutos de duración. Quería por encima de todo, que tuviera un estilo novelesco y casi barroco ... una película que el público pudiera interpretar sin dificultad, como el sueño de una anciana que se acerca al final de su vida] (Polanski, 2016, p. 239).

En la cita del director, queda comprobada esa mayor declinación hacia el tratamiento de la ambientación, más que a la narración, incluso. Esto, ya que, como recalca ese "por encima de todo", las imágenes buscaban una atmósfera más recargada, o más concretamente "novelesca y barroca" que son los adjetivos exactos que emplea el director. En el tramo del presente (a nivel narrativo), en la ciudad de Cracovia, tramo concreto del que nos ocuparemos en este ensayo, la escenografía obedece a una composición más "barroquizante" como la que Polanski menciona en la cita. Aunque luego, cuando analicemos este espacio, veremos cómo, aún obedeciendo a la pomposidad barroca, la manera de captar el escenario del aseo donde transcurre el cortometraje se acerca más a lo que conocemos como expresionismo, especialmente, en términos de iluminación.

Otra teoría que podría respaldar esa predilección más estética que narrativa es la siguiente afirmación del biógrafo sobre Polanski, Christopher Sandford (2009), la cual, curiosamente, trata sobre la no-aceptación final del ejercicio en la escuela de Lodz, donde alaban la construcción de los decorados:

Según la nota recogida en los archivos de Lodz, la película fue considerada "intrigante y compleja" ... Había mucho que admirar en los efectos y la luz (por Polanski), cuentan que escribió un miembro del tribunal. La construcción de decorados eran "meticulosos" en su conjunto. Pero el director se había excedido como guionista, posiblemente, proponiendo un final "ligeramente melodramático" (p. 71).

Esta cita pone de manifiesto ese cuidado y meticulosidad de la escenografía del corto y como esto afectaba enormemente a la narración, probablemente, refiriéndose a un suceso no muy coherente en la historia ${ }^{3}$. Demostrándose que, las imágenes del filme hablaban más por la atmósfera y por los elementos que rodean al personaje que por las narraciones o por la historia principal.

3 Posiblemente, se trate de un tramo del flashback donde vemos como vivió la guerra el hijo de la protagonista, cuando se supone que accedemos a estos recuerdos por medio de las memorias de ella y no de él.

ESCENA. Revista de las artes, 2019, Vol. 78, Núm. 2 (enero-junio), pp. 12-36 
En cuanto a las películas sobre apartamentos, la justificación de la importancia de su espacio es más evidente y clara, dado el enclave común de los apartamentos y las semejanzas argumentales de las situaciones fímicas que se producen en ellos. Sin embargo, al profundizar más en la proposición de este ejercicio teórico-práctico, surge esta reflexión comparativa de Tony McKibbin (2006) de uno de los filmes de esta trilogía, Repulsión con otra película de terror de la misma década - con 10 años de diferencia-, Carrie (1976) en cuanto al modo en que juega en el género terrorífico en sus secuencias finales:

There is maybe something puerile, then about the notion of a shock ending. If we compare the ending of Carrie with the sober concluding shot in Repulsion we can explain this puerility. Carrie goes for the immediate shock effect, the startle effect while Repulsion looks for the internally despairing ... So for De Palma ... character is subordinated to mood, Polanski is usually more interested in mood and atmosphere taken from character [Quizás hay algo pueril, sobre la noción de un final con shock. Si comparamos el final de Carrie con el sobrio plano final en Repulsión, nosotros podemos explicar dicha puerilidad. Carrie busca el efecto shock inmediato ... Para De Palma ... el personaje está subordinado al estado anímico, Polanski en general está más interesado en el estado anímico y la atmósfera extraídos del personaje] (McKibbin, 2006, p. 59).

Es la atmosfera que rodea al personaje de Carole lo que la diferencia del personaje de la adaptación filmica de Stephen King. El plano al que se refiere McKibbin es al de una fotografía enfocada en múltiples ocasiones y que ofrece respuestas alternativas al porqué de la patología mental de la protagonista. Una operación escenográfico-psicológica muy similar a otras que vemos en el resto de la trilogía y que, como tratará de desentrañar el estudio, tiene un muy posible origen ${ }^{4}$ en este cortometraje anterior donde ya se apreciaba por primera vez $z^{5}$ esa centralización estética por las atmósferas, como bien demuestran las citas bibliográficas aquí expuestas. Sin más dilación, pasamos ya al análisis comparativo.

4 También fue la primera vez en la obra de Polanski, en que se jugaba con los saltos y las elipsis en el tiempo, un juego que, como cita Vallet (2018), se repetiría en Lunas de hiel (Bitter Moon, Roman Polanski,1992). Sobre este estudio comparativo, consultar el capítulo 10 Polanski's Iconoclastic Journeys in time: When angels fall and Bitter Moon de Izabela Kalinowskai, incluido en The Cinema of Roman Polanski: Dark Spaces of the world de 2006 (John Orr y Elzbieta Ostrwska, editores).

5 "Uno de los aspectos trascendentales... se hallaba, necesariamente, en el diseño de decorados, algo a lo que Polanski apenas había prestado atención en sus cortometrajes previos debidos al carácter verista de la gran mayoría de ellos o a la abstracción ambiental de su última pieza, Lampa" (Vallet, 2018, p. 62).

ESCENA. Revista de las artes, 2019, Vol. 78, Núm. 2 (enero-junio), pp. 12-36 


\section{Los No-Hogares: espacios del sobre-aislamiento}

Este apartado y siguientes indagarán el estudio y todo lo relacionado de algún modo con el espacio del aseo en el corto y las técnicas en el uso teóricamente expresionista de la iluminación y el decorado. Un mecanismo visual que podríamos denominar como "poética de lo claustrofóbico" por el efecto de cerramiento que se consigue gracias a los mediadores escenográficos. No obstante, conviene antes explicar que significa la concesión y necesidad de inventiva del término No-Hogar que da título a este apartado. Ante una serie de espacios como los que ofrecen el aseo o los tres apartamentos, se antoja necesario un término que haga referencia a las sensaciones y trasmisiones producidas por la malsana e inextricable atmósfera, más allá de hacer referencia al mero nexo espacial. Es, entonces, cuando surge la obra Los no-lugares: espacios del anonimato. Una antropología de la sobre-modernidad de Marc Augé (1992). En esta obra, el antropólogo francés dialoga acerca de los No-Lugares, una serie de espacios que no tienen relación con la persona que los habita y que no poseen identidad con la misma. Son lugares de paso que, debido a la sobremodernidad de la que Augé habla en su ensayo, dan lugar a un nuevo tipo de aislamiento e incomunicación, así como falta de identificación. En palabras del propio estudioso:

Si un lugar puede definirse como lugar de identidad, relacional e histórico, un espacio que no puede definirse ni como espacio de identidad ni como relacional ni histórico, definirá un no-lugar... espacios que no son en sí lugares antropológicos ... no integran los lugares antiguos ... ocupan un lugar circunscripto y específico (Augé, 1992, p. 83).

Partiendo de este concepto, se crea otro bastante aplicable a lo que se aprecia tanto en las imágenes del aseo de Cuando los ángeles caen como en las tres viviendas de las películas terroríficas. Pero, con una variación significativa: no estamos hablando de No-Lugares sino de No-Hogares, pues estos cuatro espacios comparten este tipo de soledad, falta de identidad e incomunicación que reside en el término No-Lugares de Auge. Si embargo, no tanto en espacios públicos (aeropuertos, gasolineras, entre otros...) como cita el ensayista, sino en espacios que las protagonistas del corto y de las respectivas películas usan como habitáculo, como vivienda, como "hogar" en vez de "lugar".

En el caso concreto de la anciana protagonista del cortometraje, si bien es cierto que el baño que ella habita, es un espacio público por lógica y no una vivienda o apartamento (como si se da en las tres películas de terror) pero como bien explicaremos en uno de los apartados siguientes (concretamente Carácter de refugio de los No-hogares: Cuando los ángeles caen frente a Repulsión y La semilla del diablo), ella utiliza este baño claramente como un hogar e incluso como refugio, lo que lo convierte más en un teórico No-Hogar que en un No-Lugar. 
En definitiva, el concepto de No-hogar en estos filmes hace referencia a las casas o habitáculos que los protagonistas utilizan como viviendas a lo largo de las películas y el cortometraje. Pero, que, de algún modo, siempre juegan mediante determinados catalizadores escenográficos, con sus identidades o con la noción de estas. A su vez, muchos de esos catalizadores escenográficos, se hallan siempre relacionados con la sensación de aislamiento y claustrofobia. De ahí entonces, si los no-lugares de Augé son los espacios del anonimato o de la sobre-modernidad como dicta el título de su ensayo, los no-hogares son los espacios del sobre-aislamiento como dicta el título de este apartado.

Imagen 1. Panorámica de la ciudad de Cracovia al inicio de Cuando los ángeles caen

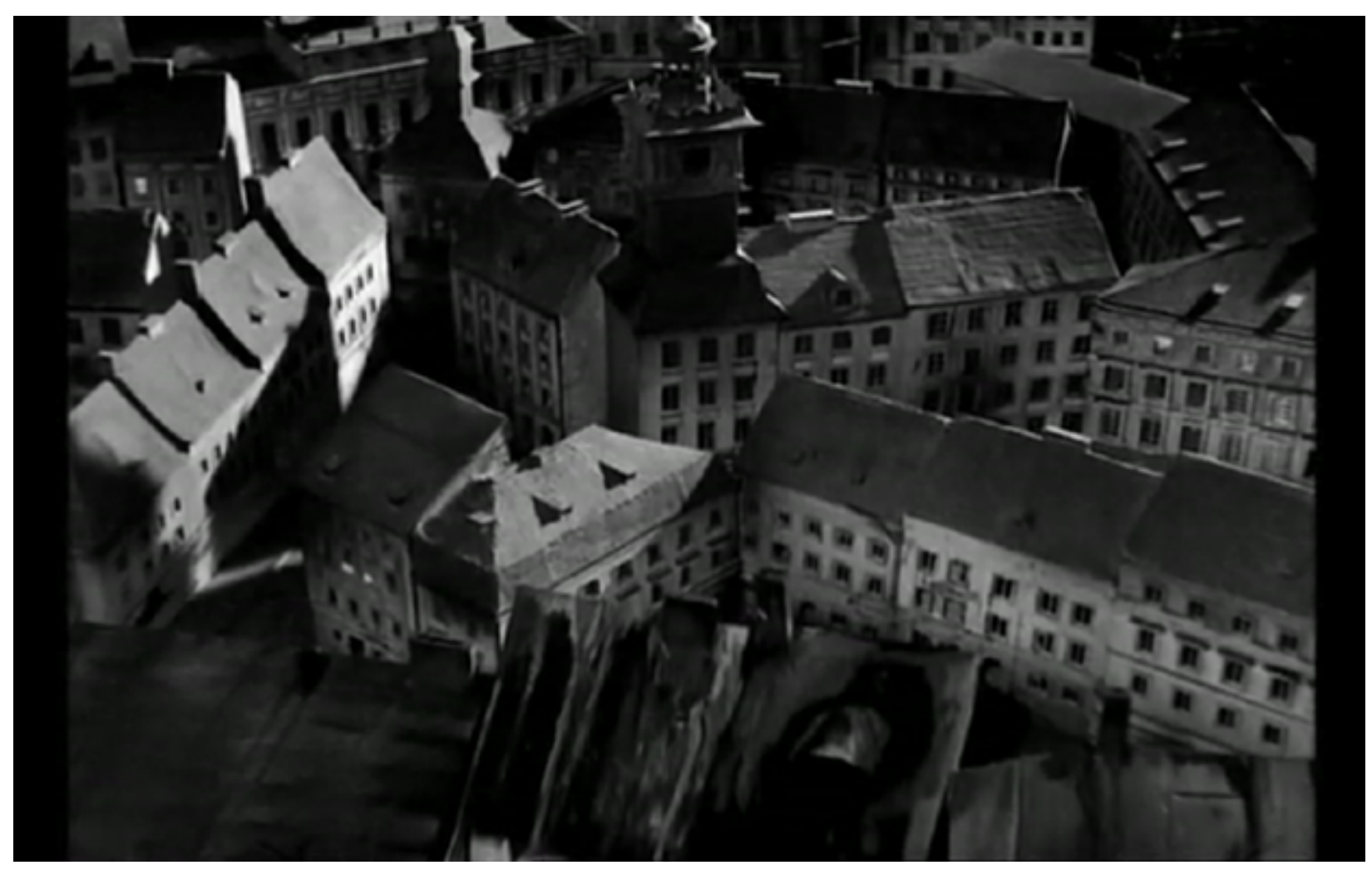

Fuente: Cuando los ángeles caen (Gdy Spadaja Anioly) Roman Polanski, 1958. 


\section{La presentación de las "prisiones": Cuando los ángeles caen y La semilla del diablo}

Comenzamos el análisis ubicándonos en la primera secuencia del cortometraje. La historia se abre con la panorámica de una Cracovia en la que apreciamos los altos edificios de época en formato de maqueta, en medio del invierno polaco (Imagen 1). Destacamos de la panorámica ese encadenamiento que se produce entre los edificios, pues todas las viviendas quedan adosadas entre sí, sugiriendo un amurallamiento, no hay casas unilaterales e independientes. De este modo, se nos sugiere una de las posibles y primeras ${ }^{6}$ muestras de esa concentración y claustrofobia visual que caracterizarán el futuro cine de Roman Polanski. Se nos presenta un mundo amurallado y aprisionado, en donde vive recluida en un "baño-vivienda", la anciana protagonista de esta historia.

En esta forma de presentación descrita, es donde podemos sugerir la conexión escenográfica de este cortometraje con La semilla del diablo. Pues, tanto la adaptación de la novela de Ira Levin, como en esta historia, se abren con una vista general de la ciudad donde viven ambas protagonistas (Nueva York en el caso de la película de 1968). En ambas oberturas, se nos sugiere la visión de un universo amurallado y claustrofóbico. Si bien es cierto que, en el inicio de La semilla del diablo la panorámica nos muestra líneas de espacio entre los mismos edificios de Central Park, es, también, como termina la secuencia. Esto parece proporcionarnos el nexo visual correspondiente: el edificio Bramtford (Imagen 2), donde se producen los satánicos acontecimientos que dan argumento al filme.

La materialidad del edificio es la posible clave visual. Hasta la toma del Bramtford en la imagen, los edificios que hemos visto mientras circulan los créditos están recubiertos de hormigón contemporáneo, en claro contraste material con el edificio Bramtford erigido en Piedra y más cercano a la concepción de una catedral gótica que a la concepción de un edificio de pleno siglo XX como los que rodean a la ciudad. De hecho, se muestra aislado ${ }^{7}$ del resto de la gran manzana. Sobre esto, cita muy bien, Montse Hormigos Vaquero (2006) en su análisis publicado de La semilla del diablo:

6 Este no fue el primer corto dirigido por el cineasta.

7 Un detalle que conviene tener en cuenta de cara a la presentación de La semilla del diablo es la base real del lugar donde se ambienta lo que se llama "edificio Bramtford" en la película, que es el edificio Dakota, que históricamente fue núcleo de rituales satánicos perpetrados por Aleister Crwoley (igual que en el filme). El caso es que durante los meses de construcción del edificio de octubre 1880 a octubre 1884, la distancia del edificio frente al área residencial -en aquel periodoequivalía a la distancia de Nueva York con Dakota del Norte. Este detalle de la toponimia del lugar real de rodaje del filme posibilita la interpretación de esa prisión "alejada" y diferenciada del resto 
La apertura tiene mucho que ver con el significado del film: en un ambiente cosmopolita y luminoso, emerge el oscuro y misterioso edificio Bramtford. La extrañeza visual del Bramtford, que parece un inmueble fuera del tiempo y del espacio, está relacionada con los acontecimientos que más tarde allí se desatan, con el hecho de que en una ciudad de los 60 , existían ritos antiguos como la brujería y el satanismo (p. 26).

Imagen 2. Panorámica de la ciudad de Nueva York al inicio de La semilla del diablo.

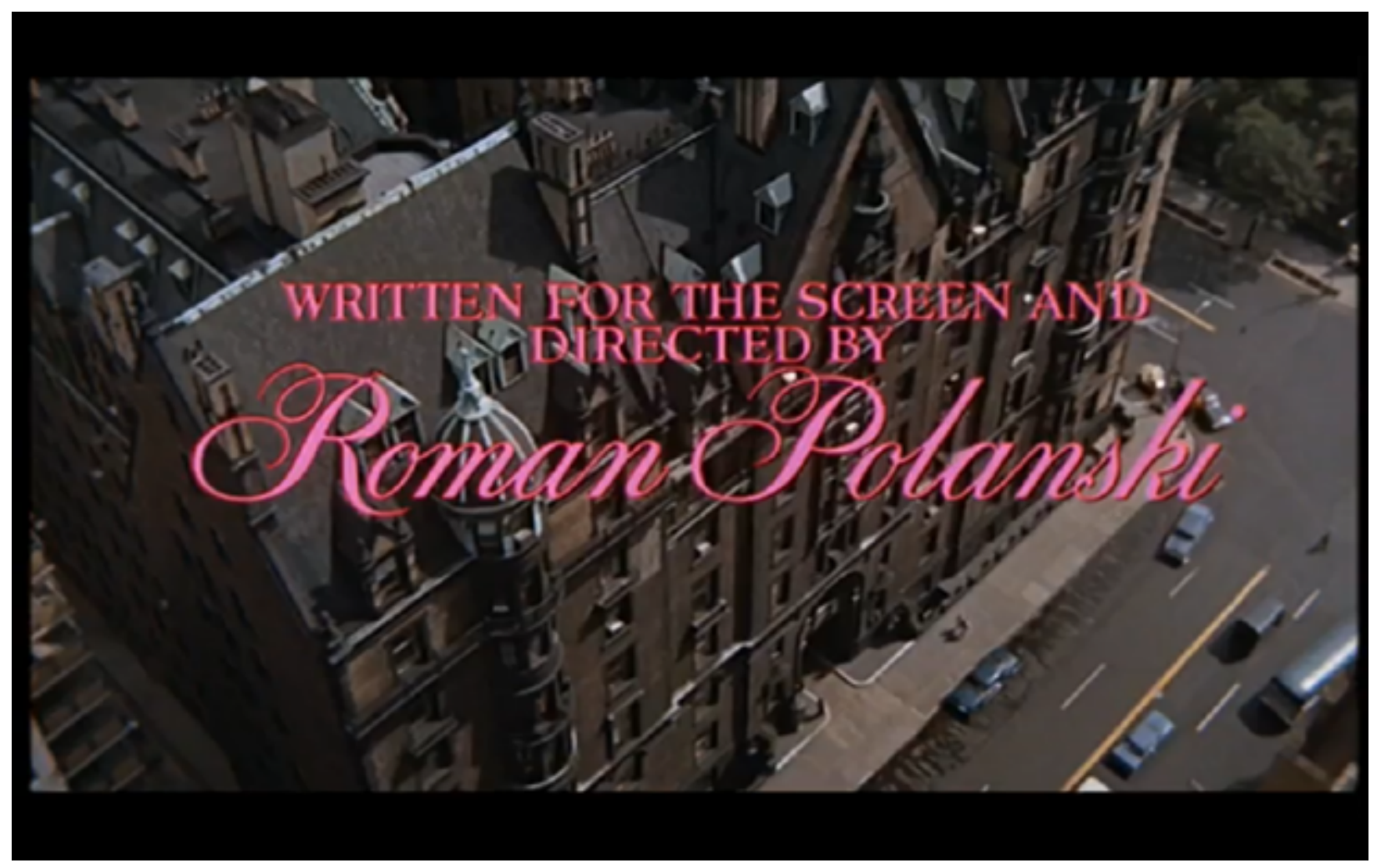

Fuente: Polanski (1968).

La "prisión" existe en ambas presentaciones, pero manifestada de formas muy diferentes. En una (Cuando los ángeles caen), recorre toda la ciudad y, en otra (La semilla del diablo), se muestra apartada de la misma. El nombre de "prisión" se antoja aplicable al

de la ciudad en las imágenes del filme. Máxime teniendo en cuenta que el inicio en la novela de donde se adapta no era el mismo en ningún momento. 
espacio del baño donde vive la anciana protagonista del cortometraje, ya que descubriremos en el corto -por medio de los flashbacks de sus recuerdos a todo color- que es un espacio al que ella se vio obligada ${ }^{8}$ a confinarse, no es un lugar que ella escogió, personalmente. El edificio Bramtford, el espacio donde la protagonista Rosemary (Mia Farrow) se aloja, es una elección al principio del filme. Pero, una vez encinta es "retenida" en el edificio por las excesivas atenciones de los vecinos satánicos, quienes la manipulan y drogan mediante medicinas o brebajes para mantenerla en su apartamento y poder usar a su futuro hijo como "Mesías" de sus rituales satanistas.

A su vez, tanto el apartamento de La semilla del diablo como el baño-vivienda de Cuando los ángeles caen comparten el ser una metáfora plástica de parte de lo que viven las protagonistas. El apartamento del Bramtford puede leerse como figuración del vientre materno de Rosemary "ya que alberga a los protagonistas, por ser el sitio donde Rosemary va a ser fecundada y donde también parirá, y por tratarse del lugar al que los personajes siempre retornan" (Villarquide, 2006, p.19). En cambio, el baño de Cuando los ángeles caen podemos verlo como metáfora de los recuerdos personales de la protagonista, ya que alrededor de este espacio comienzan a circular una serie de personajes como un soldado con el uniforme prusiano o un mendigo con una jaula. La serie de atuendos retro-atraen a la anciana a su juventud, cuando conoció a su pareja que era un soldado con este uniforme o a su hijo que le gustaba jugar a torturar animales (como ese pobre pájaro enjaulado) antes de que ambos murieran en la guerra.

\section{Los baños (I): Cuando los ángeles caen y Repulsión}

Un operador escenográfico común entre el corto y las tres películas, concretamente, en Repulsión y El quimérico inquilino es el espacio del baño. Un espacio que en los tres casos se "rebela" contra sus identidades. Recordemos que, la falta de identidad era un rasgo que residía en el término de los No-Lugares presente en la obra de Augé y que se repite en estos No-Hogares. En este caso, nos centraremos en la conexión del cortometraje con la primera de las películas de la trilogía de apartamentos: Repulsión.

Comenzaremos por Cuando los ángeles caen, donde el baño es directamente la "vivienda". La primera vez que accedemos al entorno del baño, la entrada guarda más relación con el acceso o la llegada a una gruta que con la entrada a un espacio público. En dicho

8 En la trama en flashbacks del cortometraje, apreciamos que la protagonista se vio obligada a trasladarse del campo a la ciudad para trabajar de limpiadora primero en una casa y ya luego en estos baños públicos de los que es "propietaria".

ESCENA. Revista de las artes, 2019, Vol. 78, Núm. 2 (enero-junio), pp. 12-36 
plano del acceso (Imagen 3), quedan remarcadas por la iluminación las notables limitaciones del espacio: una vez más, la sensación claustrofóbica se hace con el sentido visual de la imagen, del mismo modo que se antecedía en la presentación del cortometraje.

Imagen 3. Acceso al baño/ No-Hogar en Cuando los ángeles caen

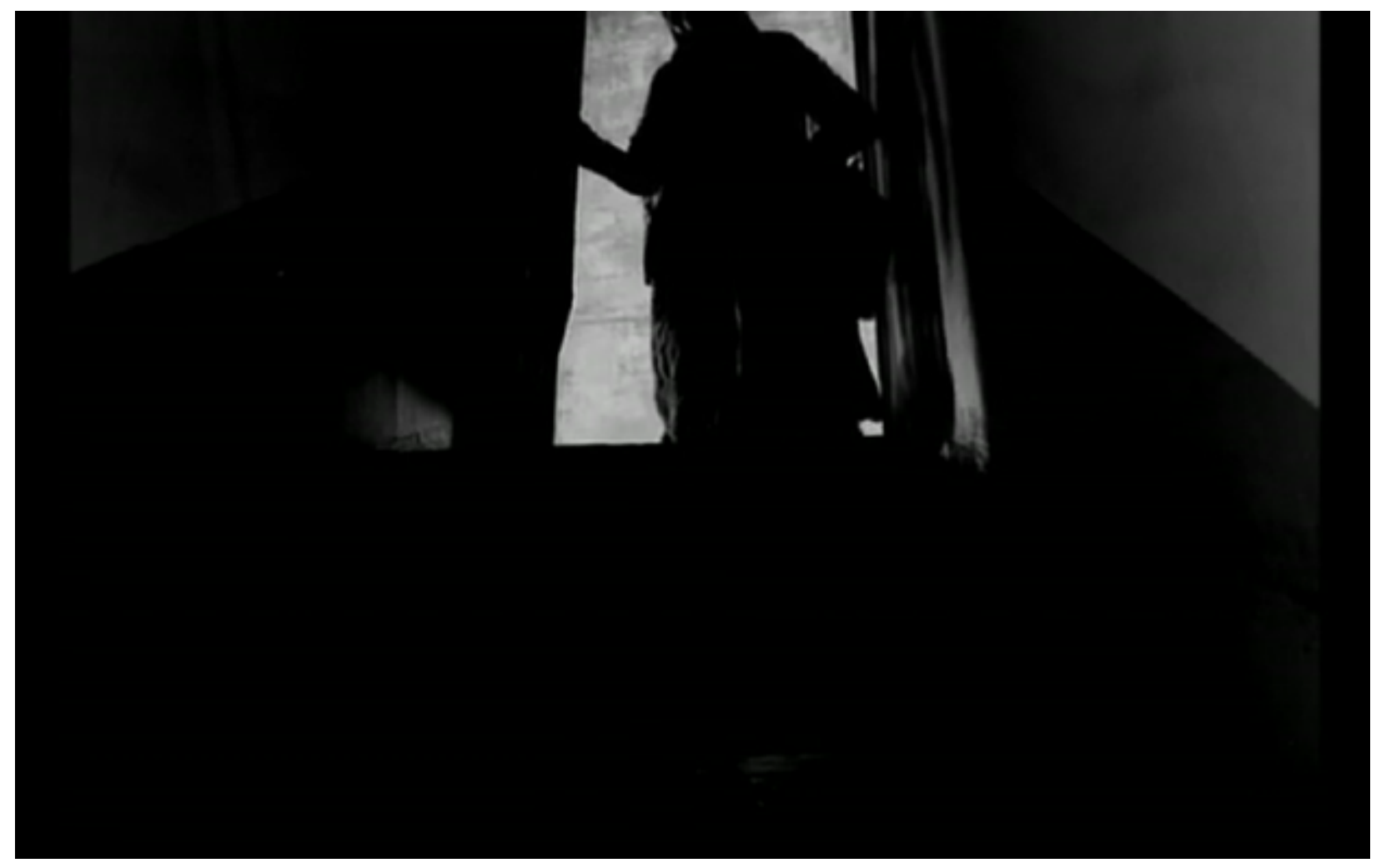

Fuente: Polanski (1958).

En Repulsión, el sentido claustrofóbico-visual es muy similar. Hay un momento dado en el que la protagonista también accede al espacio del baño; en una imagen con claros paralelismos visuales a la entrada de la anciana en el baño de Cuando los ángeles caen (Imagen 4). En la misma imagen de la que hablamos, no solo se resalta visualmente el cerramiento espacial, sino, también, simbólicamente por medio de los brazos masculinos que flanquean a la protagonista. Debido a que Carole (Catherine Deneuve), la protagonista de Repulsión, sufre una patológica animadversión hacia el sexo masculino, de ahí que muchas 
de las "alucinógenas" transformaciones de la arquitectura del apartamento sean metáforas acerca de la virilidad, como lo son estos robustos brazos que se desarrollan en las paredes. Tanto este uso de la iluminación, como el carácter simbólico nos remiten al expresionismo dado que, como dice Jean Mitry (2002) en su volumen sobre Estética y psicología del cine acerca del expresionismo:

Cada objeto está cargado de significación ... la acción condensa los hechos sin retener sino lo que tienen de esencial. ... Los objetos más simples, la puerta giratoria, los uniformes son otros tantos signos (p. 280).

Imagen 4. Acceso al baño del No-Hogar en Repulsión

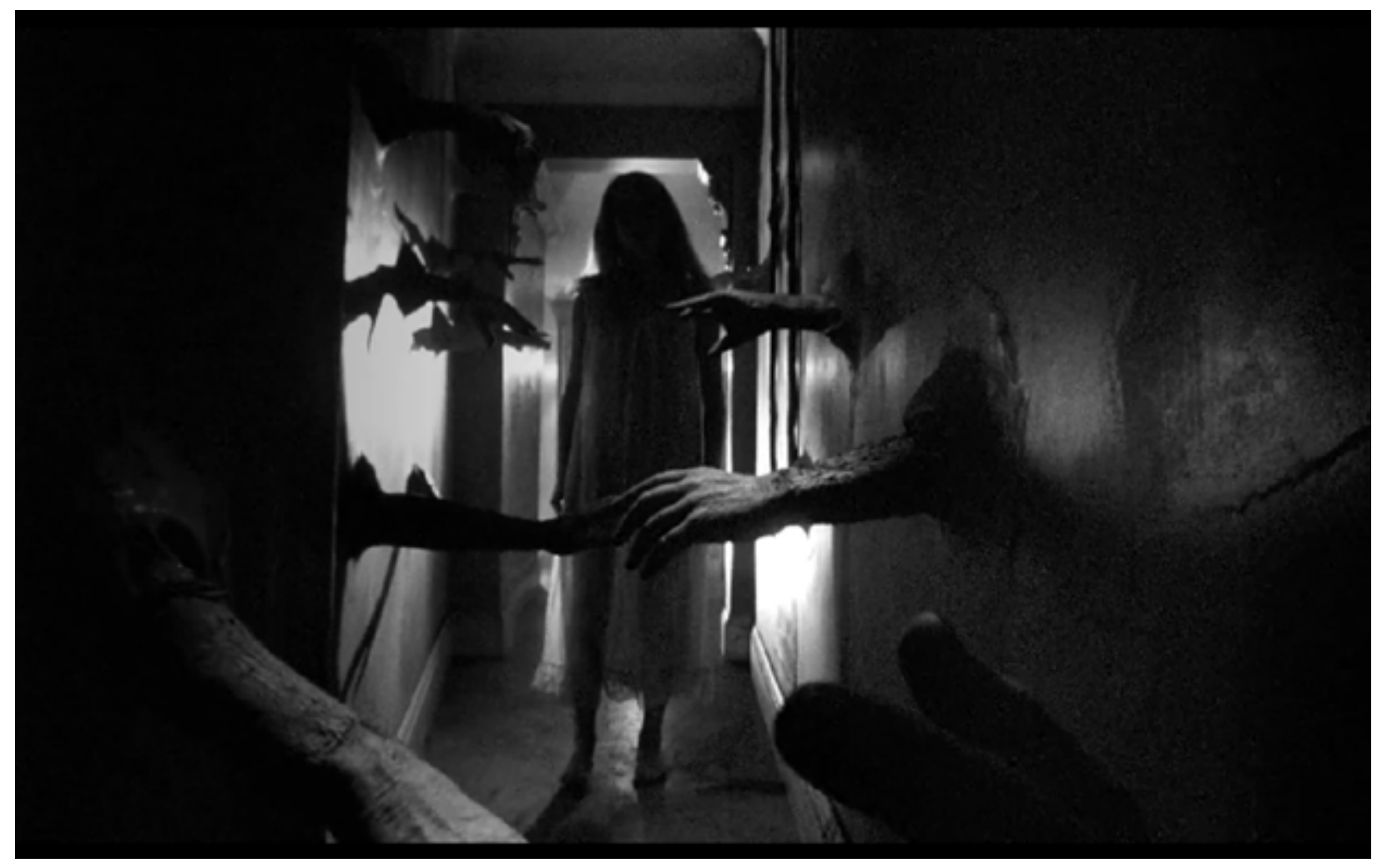

Fuente: Polanski (1965).

9 En el filme, la involución psicológica del personaje protagonista se muestra visualmente por medio de múltiples y extrañas transformaciones del espacio. 
De este modo, en Repulsión apreciamos uno de esos signos que vendrían a ser los brazos masculinos. Mientras que, el detalle de la cita de Mitry sobre "condensar los hechos sin retener sino lo que tienen de esencial", se puede apreciar en la imagen escogida del acceso de la anciana al baño en Cuando los ángeles caen. Dado que, esa oscuridad y el escaso uso de iluminación escogida remarcan la pertenencia y la importancia de esa protagonista anciana en ese espacio, eso es lo esencial en este momento.

\section{Los baños (II): Cuando los ángeles caen y El quimérico inquilino}

Si comparamos el baño del cortometraje con el baño de El quimérico inquilino veremos que, también comparten esa formalidad visual claustrofóbica de los dos planos anteriores ya comentados. En el filme de 1976, el aseo es un cubículo que tiene de ancho lo justo para que quepa el cuerpo del protagonista. Pero, lo que realmente es interesante para el estudio comparativo de ambos espacios es el uso de la decoración historicista en los dos baños. Decoración, posiblemente, alusiva a la identidad "pasada" de algunos personajes. A continuación, explicaremos porqué.

Imagen 5. La flor en el flashback en Cuando los ángeles caen

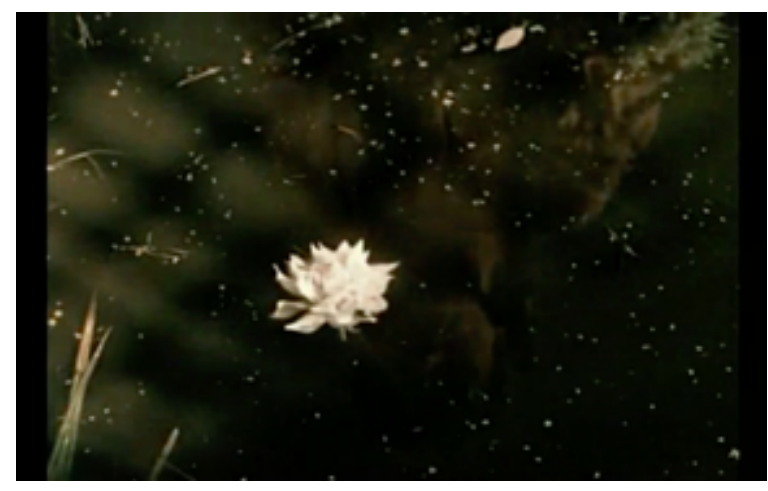

Imagen 6. La flor en la decoración del baño en Cuando los ángeles caen

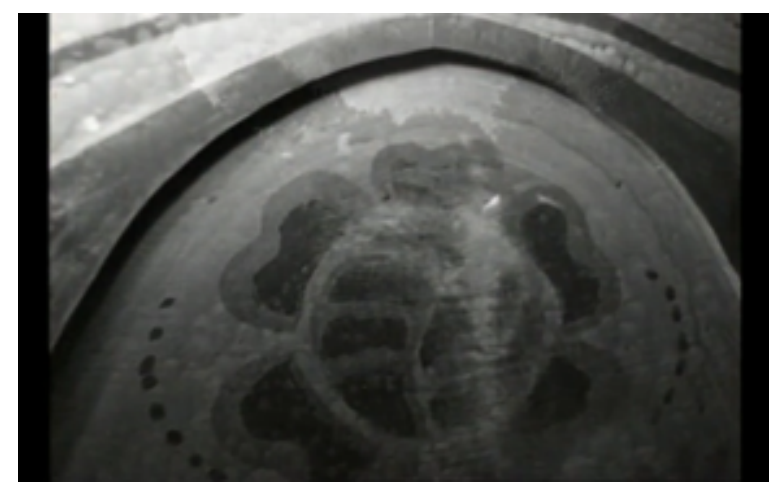

Fuente: Polanski (1958). 
El baño donde vive la anciana posee una decoración art-decó con múltiples motivos y formas vegetales. Luego, en los flashbacks, las imágenes nos muestran cómo la anciana vivió, durante un largo periodo de su juventud como campesina, lejos de la ciudad de Cracovia, antes de la Primera Guerra Mundial. También, se aprecia cómo se vio obligada a trasladarse a la ciudad polaca hasta acabar usando este baño como "hogar". De ahí, ese posible uso de las formas vegetales, aludiendo a ese pasado campestre, a primera vista, inimaginable para un personaje así, pero que, descubrimos gracias al empleo constante de fundidos encadenados y otras técnicas que conectan el escenográfico motivo vegetal con su correspondiente recuerdo en flashback. Como es el caso de la imagen de una flor blanca en el río dentro del flashback (Imagen 5) evocada en el presente narrativo, por medio de la decoración de una de las puertas del baño (Imagen 6).

En El quimérico inquilino, la decoración historicista escogida es la decoración jeroglífica egipcia ${ }^{10}$ (Imagen 7). En este caso, el juego se da con el protagonista de la historia o, mejor dicho, en el personaje que este se transforma. Conviene contextualizar argumentalmente: en el filme, el personaje protagonista de Trelkovsky (Roman Polanski) sufre de un desdoblamiento de la personalidad, por el que se va transformando ${ }^{11}$ en la anterior y fallecida inquilina de su nuevo apartamento. A lo largo de las secuencias descubrimos que, dicha inquilina era una gran apasionada de la historia y cultura egipcias. Por lo tanto, hay un posible significado en esa decoración de la pared acerca de la transformación de identidad que Trelkovsky está viviendo en el filme. Esta visión se ve reforzada, ya que a posteriori de este momento, el personaje se trasviste en la inquilina y pierde la noción psicológica absoluta sobre sí mismo.

\footnotetext{
10 Una decoración que tampoco aparece descrita en la novela de Roland Topor en que está basada; algo que también se daba, como explicábamos antes, en el caso de la presentación de los créditos sobre la ciudad de Nueva York en La semilla del diablo y su original literario de Ira Levin. Dos detalles de la adaptación que subrayan más el mecanismo escenográfico como estilema visual de estos filmes.

${ }^{11}$ En este aspecto, la pérdida de identidad del personaje principal para transformarse en la anterior inquilina, apreciamos un rasgo -la falta de identidad- que comparte el apartamento de Trelkovsky con el No-Lugar de Marc Augé, puesto que los No-Lugares son espacios carentes de identidad y relación con las personas que los habitan. En este caso, Trelkovsky, quien llega nuevo a habitar este apartamento y pierde psicológicamente su identidad durante la estancia. Lo que hace que podamos catalogar el apartamento de Trelkovsky como un No-Hogar.
}

ESCENA. Revista de las artes, 2019, Vol. 78, Núm. 2 (enero-junio), pp. 12-36 
Imagen 7. Jeroglíficos egipcios en el baño de El quimérico inquilino

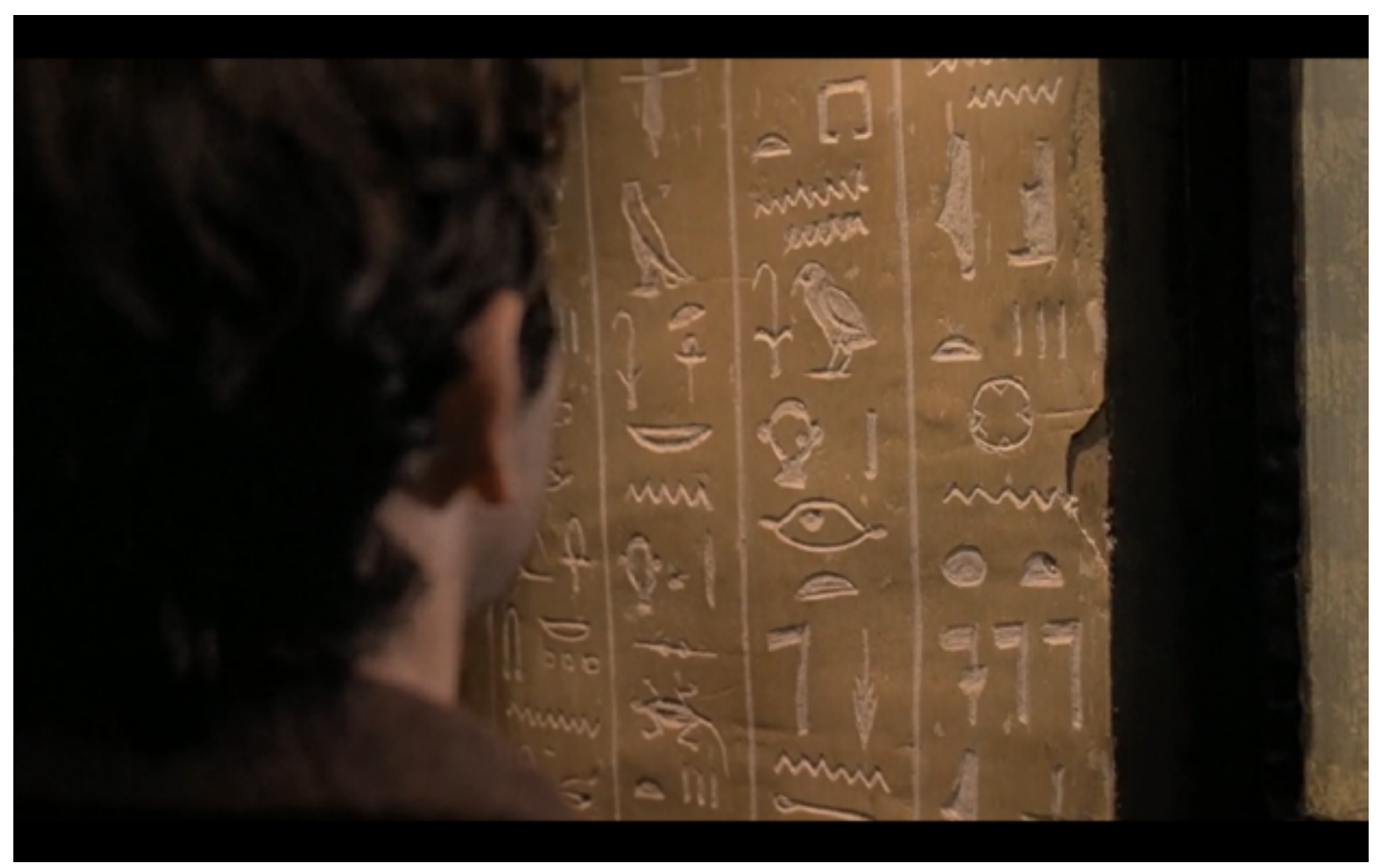

Fuente: Polanski (1976).

De esta manera, las decoraciones de ambos baños, una más naturalista y otra más historicista, nos retro-atraen a dos identidades pasadas. La campestre de la anciana y la aficionada a la egiptología de la anterior inquilina. Conocemos un detalle importante de sus psicologías mediante ambas decoraciones en dichos aseos.

\section{El techo de baldosas: Cuando los ángeles caen y El quimérico inquilino}

Tanto en el corto, como en la tercera entrega de la trilogía de apartamentos (El quimérico inquilino) hay un operador escenográfico común que funciona como complemento y que separa dos realidades distintas, en términos de percepción psicológica: el techo de baldosas. En ambos casos, vuelve a ser un elemento que evoca, una vez más, a la claustrofobia visual debido a la composición en barrotes de este techo, que nos sugieren formalmente una jaula. 
Recordemos que, en la presentación del corto sugeríamos que se nos presentaba una "prisión", pues he aquí otra metáfora escénica de esto. Una "prisión" cuyas captaciones más interesantes se dan en los múltiples planos que captan la marquesina en contrapicado, lo cual deja ver los pies de los viandantes del exterior. Tal como si el subsuelo en el que está el baño fuera otro mundo, al que, únicamente, ella pertenece. Esta lectura también la comparte Alexander Tylski (2006) y que, además, añade la posibilidad del techo de baldosas (Imagen 8) como otro conector escenográfico más, junto con los recuerdos de la anciana:

Quant aux images, elles se chargent de décrire le décor, rendu en fait vivant par ces sons hors champs(bruit de pas exterieurs, reverbation, etc...). Ainsi, les pas au plafond de verre rappelle de souvenirs à cette vieille dame. [En cuanto a las imágenes, estas son las responsables de describir el escenario, que se siente muy vivo por esos sonidos fuera de campo (pasos externos, reverberación, entre otros.). Es entonces, cuando los pasos sobre el techo de vidrio traen recuerdos a esta anciana] (p. 98).

Imagen 8. El techo de baldosas en Cuando los ángeles caen

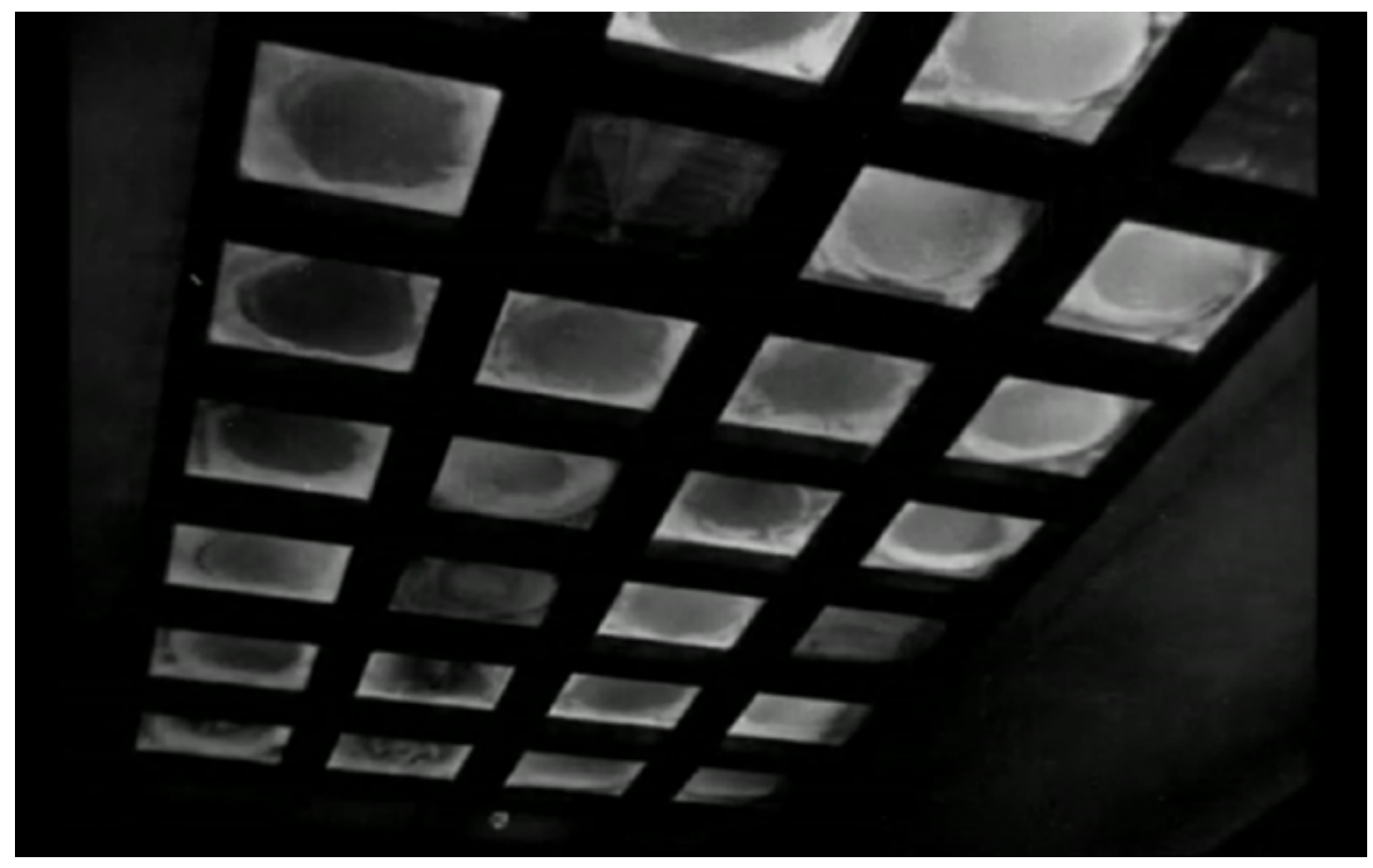

Fuente: Polanski (1976). 
En el caso de la historia de Trelkovsky, también apreciamos ese techo de baldosas (Imagen 9) como catalizador de dos mundos y, del mismo modo, dos realidades que viven en la cabeza del protagonista. A diferencia del corto, aquí el operador escenográfico obedece a una estructura circular narrativa que, según algunos autores es propia del cine de Roman Polanski, puesto que "con las honrosas excepciones de Chinatown (Roman Polanski, 1974) y La novena puerta (Roman Polanski, 1999) ... todas sus películas conformarán un círculo perfecto" (Feeney \& Duncan, 2006, p. 16). El techo de baldosas es la primera pieza que Trelkovsky conocerá de su patio de vecinos y también la última.

Imagen 9. El techo de baldosas en El quimérico inquilino

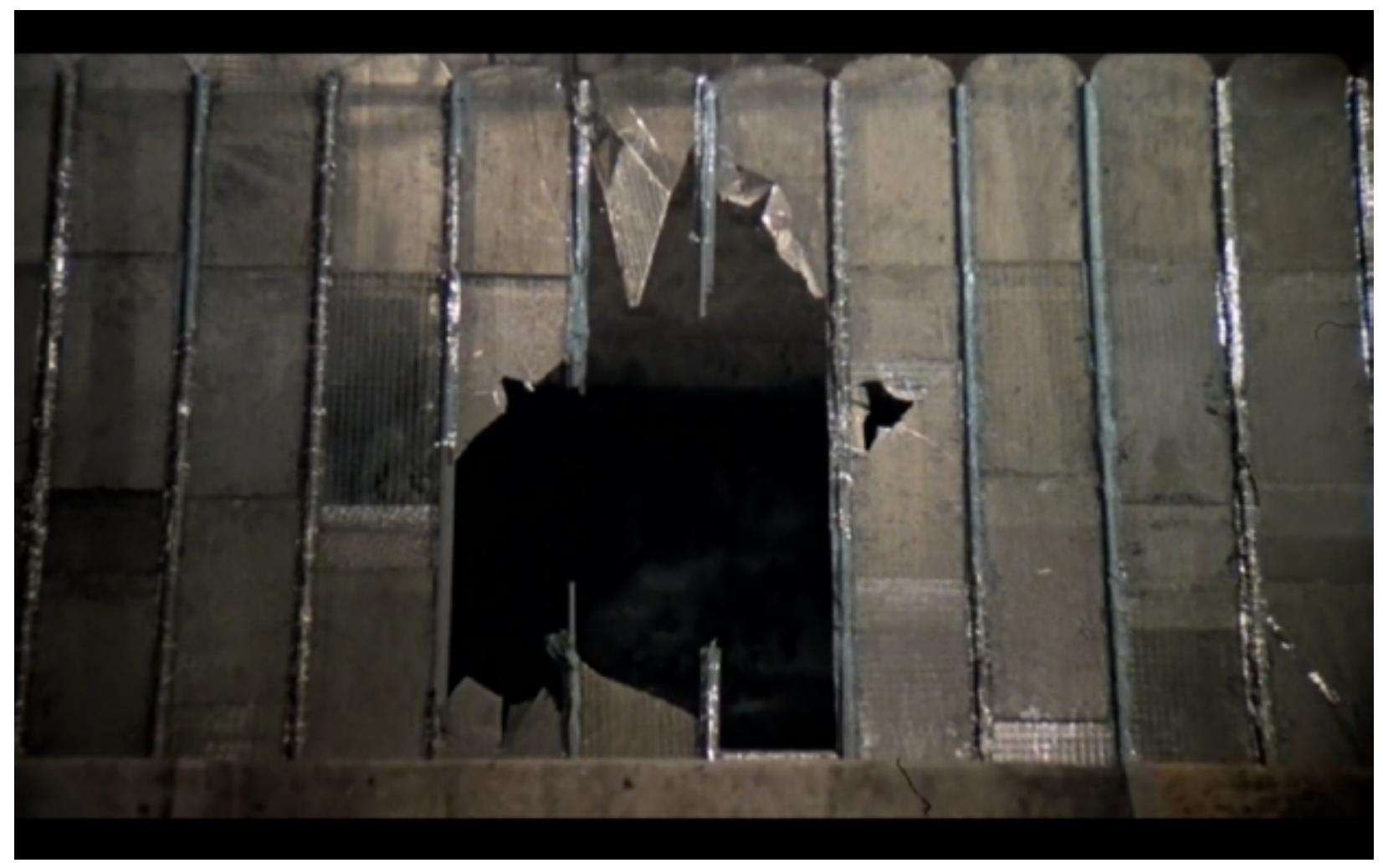

Fuente: Polanski (1976).

Esta no es la única característica que comunica ambos operadores en el corto y en el filme ya que, en el final el mismo protagonista saltará por la marquesina en el punto más alto de sus enajenaciones mentales. Así, cierra el ciclo mortal que inició la anterior inquilina del apartamento quién, por ese mismo recoveco se suicidó. De ahí, que al igual que en el 
corto, consideremos el techo de baldosas de la película, como un catalizador de ambas realidades: la realidad del protagonista en ciernes de su locura y la realidad que ven el resto de vecinos del patio, quienes contemplan el suicidio en la secuencia final.

También apreciamos una síntesis visual aún mayor a nivel plástico y de texturas en ambos techos. Concretamente, en las dos respectivas roturas que sufren. En ambos casos, corto y filme, la composición fragmentada da lugar a que se hagan "figurativas" las respectivas enajenaciones mentales de los dos personajes protagónicos. En el caso de la anciana, cuando la alucinación de un ángel $\left.\right|^{12}$ se le aparece para redimirla. En el caso de Trelkovsky, cuando se vuelve a ver a sí mismo en el hospital, al inicio del filme, justo antes de comenzar su declive psicológico.

\section{El carácter de refugio de los No-hogares: Cuando los ángeles caen frente a Repulsión y La semilla del diablo}

Como aludíamos al inicio del análisis, nominábamos al habitáculo del baño en Cuando los ángeles caen como un ejemplo de No-Hogar, pese a tratarse de un baño público, ya que la anciana emplea este como un hogar. Eso se demuestra en el cuidado que le ofrece, más allá de la mera higiene del habitáculo, pues, prácticamente, cuida el sitio de un modo que nos recuerda más a un campo de cultivo personal (Imagen 10). De esto, habla bien en la siguiente cita de Tylski, una vez más:

elle descend les marches et nous la découvrons dans ses gestes quotidiens. Elle place des pastilles désodorisantes dans les urinoirs et sème de la poudre par fumée sur le sol. Elle est semeuse, son geste nous rappelle inévitablement celle d'un paysanne dans un champ. Puis, un travelling avant nous fait enfin faire connaisance avec ce visage labouré. ... Nous sommes inextricablement projeté dans le profond [ella baja lentamente las escaleras, de forma que la descubrimos realizando sus gestos cotidianos. Coloca una serie de pastillas desodorizantes y siembra polvos de talco perfumados en el suelo. Su gesto nos recuerda, inevitablemente, al gesto de una campesina en el campo. Después se desarrolla un travelling de seguimiento, donde se nos hace ver su laborioso rostro. Estamos inextricablemente proyectados en lo profundo de sus pensamientos] (Tylski, 2004, p. 98)

En este aspecto, este tratamiento de la escenografía se corresponde más con Repulsión y con La semilla del diablo, aunque, en el primer caso, como un rasgo común y, en el segundo caso, más por el contraste de ambos tratamientos. En el filme protagonizado por Catherine Deneuve, el hogar y los elementos que lo conforman se ven como un

\footnotetext{
${ }^{12}$ Aludido escenográficamente de forma premonitoria en la presentación del corto por medio de las figuras de los ángeles campaneros.
}

ESCENA. Revista de las artes, 2019, Vol. 78, Núm. 2 (enero-junio), pp. 12-36 
refugio de la protagonista, del mundo exterior masculino, como bien reflejan las acciones de la ella en el habitáculo, ya que es el "espacio en el que se limpia de la realidad masculina de afuera” (Padilla Díaz, 2017, p. 150).

Imagen 10. El No-Hogar como refugio en Cuando los ángeles caen.

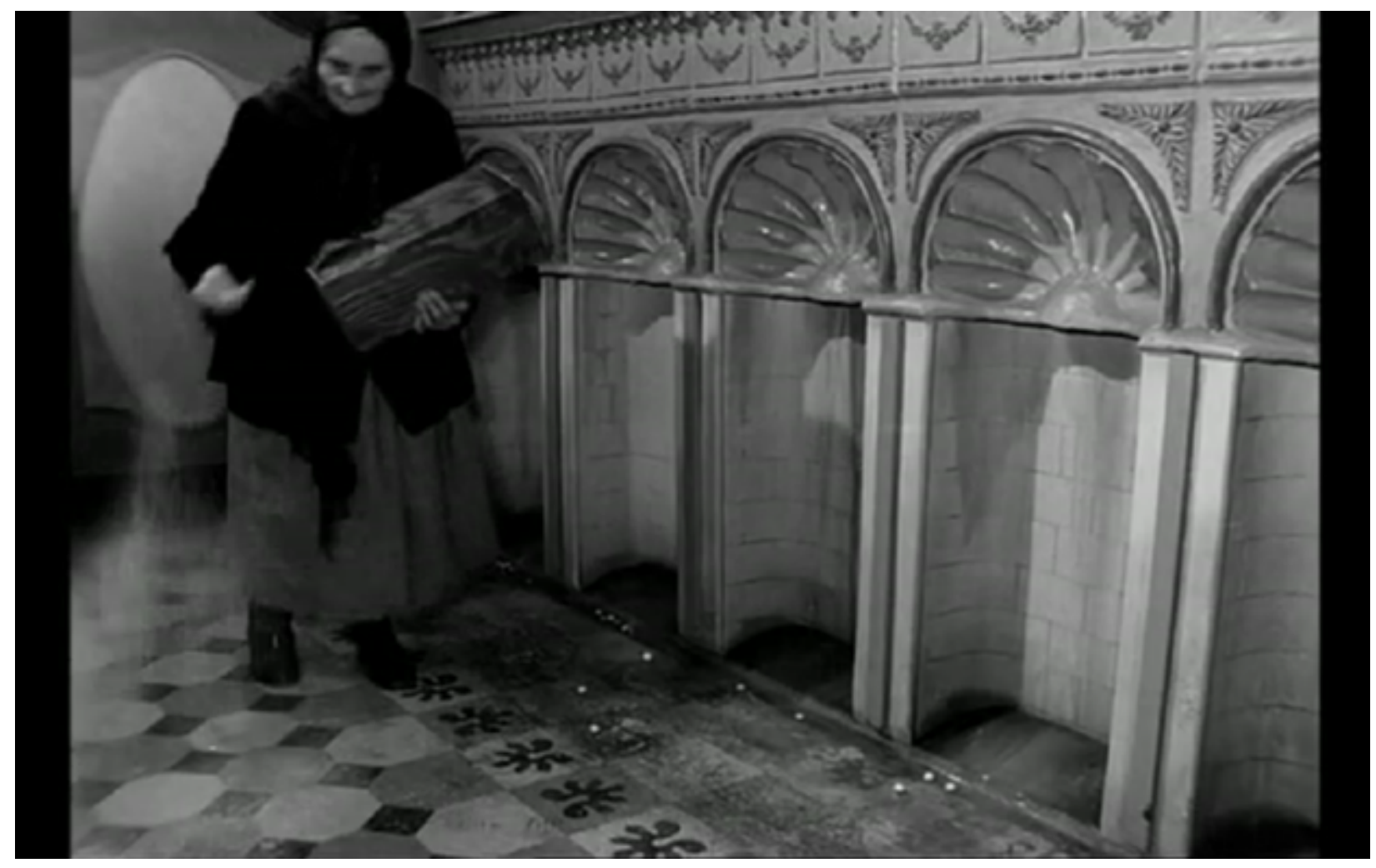

Fuente: Polanski (1958).

En La semilla del diablo, en cambio, no es el hogar un refugio - a diferencia de la película de 1965 y el corto - sino que, el mundo exterior al mismo resulta una prisión ya que, como cita Hormigos:

Rosemary está más segura paseando entre las bulliciosas calles de Nueva York que dentro de su propio hogar, constantemente amenazado por la secta satánica ... Esta es la paradoja que pone en juego Polanski que, además, está relacionada con la crítica del director a la familia como institución: la casa no es el refugio, Rosemary no está segura en ella y huye a la calle (que típicamente se muestra como lugar de indefensión e inseguridad) (2006, p. 63). 


\section{Conclusión}

Así pues, concluimos el siguiente estudio señalando, una vez más, que estos cuatro espacios que designamos como No-Hogares quedan relacionados por su carácter de refugios para las protagonistas, pese a las características patológicas o terroríficas que poseen. La evolución de dichos espacios, durante el metraje, es paralela a la pérdida de identidad y percepción psicológica de los personajes, lo cual responde a la posibilidad de cómo las imágenes de estos filmes de Polanski configuran una serie de programas escenográfico-psicológicos. Tanto en Cuando los ángeles caen, como en la trilogía de la reclusión/ apartamentos, hemos visto como los operadores u marcadores visuales escenográficos tales como la presentación de las ciudades donde están los No-Hogares, el baño o el techo de baldosas sirven como catalizadores de lo que viven los protagonistas de las historias. Del mismo modo que, en los catalizadores del corto y los tres filmes se repiten juegos visuales: como el sentido claustrofóbico y la iluminación expresionista; o formas como las decoraciones historicistas; así como, las roturas en ambos techos de baldosas.

Sin embargo, los rasgos apreciados en torno a estos No-Hogares no siempre tienen, necesariamente, que hallarse en torno a películas donde la atmosfera escénica evoque, de algún modo, cierto pesimismo existencial, como el caso de la trilogía de apartamentos o la citada en la introducción El escritor. Un importante ejemplo de ello es el filme posterior a la trilogía terrorífica aquí comentada Tess (Roman Polanski, 1979) donde la atmósfera escenográfica, mucho más lumínica, evoca más al romanticismo pictórico, que al expresionismo visto en este escrito. Aun así, eso no es óbice para que apreciemos, aunque quizás de forma más leve, ciertos rasgos como la claustrofobia visual o la sugerencia de formas enjauladas, en alusión a una característica del protagonista o algún tormento que el mismo vive o vivirá. Es el ejemplo de una secuencia en la que, la protagonista Tess (Nastassja Kinski) aprecia, atentamente, unas jaulas de oro en el primer tramo de la película (Imagen 11), en alusión a su mal devenir personal, en el resto de la misma. Puesto que, a posteriori de esta contemplación, será forzada físicamente por el dueño de la casa en la que trabaja y donde se hallan las jaulas de oro. Todo esto ayuda a realzar la necesidad de entender y analizar este "dispositivo escenográfico-psicológico" como la posibilidad de una delgada, pero apreciable, línea visual que une gran parte de la filmografía de Roman Polanski. 
Imagen 11. Las jaulas de oro enmarcando y pronosticando el futuro de Tess

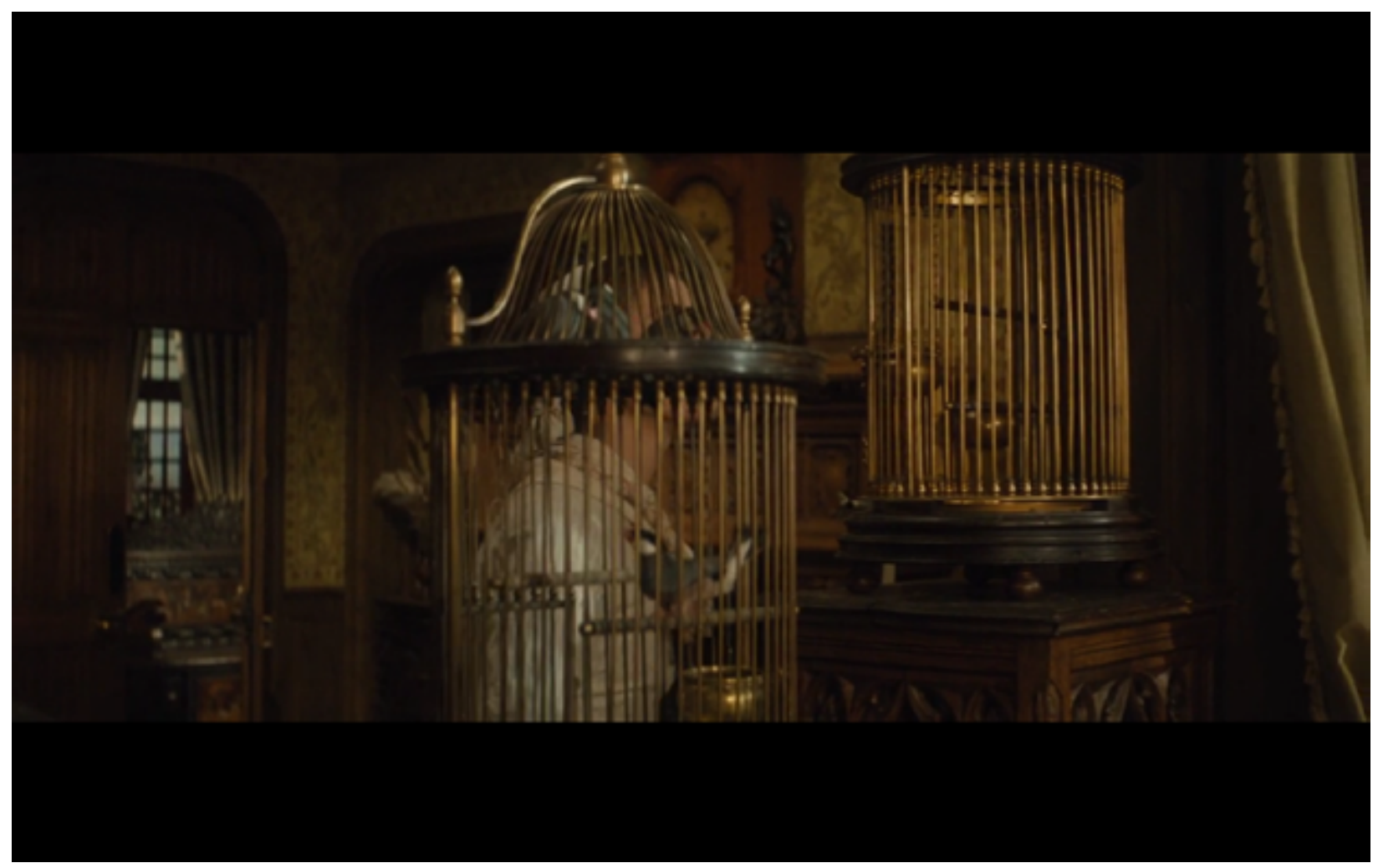

Fuente:Polanski (1979).

\section{Referencias}

Augé, M. (1992). Los No-Lugares: Espacios del anonimato. Una antropología de la sobremodernidad. Barcelona: Gedisa.

Avron, D. (1990). Los colosos del cine: Roman Polanski. Barcelona: Cinema Club Collection.

Bazin, A. (1990). Qué es el cine. Madrid: Ediciones Rialp S.A.

Feeney, X. \& Duncan, P. (2006). Roman Polanski. Madrid: Taschen.

Goscillo, H. (2006). Polanski's existential body -as Somebody, Nobody and anybody. En Orr, J. \& Ostrowska (Ed.), The cinema of Roman Polanski: Dark Spaces of the world (pp. 22-38). Londres: Wallflower Press. 
Hormigos, M. (2003). Guía para ver y analizar La Semilla del diablo. Barcelona y Valencia: Octaedro y Nau Libres.

King, S. (2016). Danza Macabra. Madrid: Valdemar Intempestivas.

McKibbin, T. (2006). Polanski and the horror from within. En Orr, J. \& Ostrowska (Ed.), The cinema of Roman Polanski: Dark Spaces of the world. (pp. 51-62) , Londres: Wallflower Press.

Mitry, J. (1963). Estética y psicología del cine 1: Las estructuras. Madrid: Siglo XXI de España Editores S.A

Moldes, D. (2005). Roman Polanski: La fantasía del atormentado. Madrid: Ediciones JC.

Padilla, A. R. (2017). La poética claustrofóbica de los No-Hogares en Repulsión (Repulsion, Roman Polanski, 1965). Fonseca Journal of Communication, 14(14),147-166. DOI: http://dx.doi.org/10.14201/fjc201714147166

Polanski, R. (1958). Gdy Spadaja Anioly [Cortometraje]. Polonia. Panstwowa Wyzsza Szkola Filmowa.

Polanski, R. (1965). Repulsion. [Película]. Reino Unido. Columbia Pictures/ Compton Films.

Polanski, R. (1968). Rosemary's Baby. [Película]. EEUU. Paramount Pictures.

Polanski, R. (1976). Le Locataire. [Película]. Francia. Paramount Pictures.

Polanski, R. (2016). Roman par Polanski. París: Fayard.

Sandford, C. (2009). Polanski Biografia. Madrid: Akal.

Tylski, A. (2004). Roman Polanski ses premiers films polonais. Lyon: Aléas.

Vallet, J. (2018). Roman Polanski. Madrid: Cátedra Signo e Imagen.

Villarquide, M. (2006). Roman Polanski: Visiones siniestras de lo cotidiano. Cuadernos de documentación multimedia,17, 26-52. DOl: https://doi.org/10.5209/CDMU.58924 